\title{
POJEMNIKI I ROŚLINY KUBŁOWE W HISTORYCZNYCH PARKACH I OGRODACH
}

\author{
Halina Laskowska, Margot Dudkiewicz, Paweł Szot \\ Katedra Roślin Ozdobnych i Architektury Krajobrazu, Uniwersytet Przyrodniczy w Lublinie \\ Department of Ornamental Plants and Landscape Architecture, University of Life Sciences in Lublin \\ e-mail: malgorzatadudkiewicz@o2.pl
}

\begin{abstract}
Streszczenie: Pojemniki są ważnym elementem wyposażenia zabytkowego ogrodu. Kwiaty były uprawiane w donicach i misach już w czasach Homera. W ogrodach historycznych XVII, XVIII i XIX wieku pojemniki ustawiano w punktach, które chciano podkreślić, formowano z nich rzędy i rytmiczne kompozycje. Donice ustawiano nad brzegami zbiorników wodnych, na balustradach, tarasach i schodach.
\end{abstract}

Słowa kluczowe: pałac, dwór, pojemniki, rośliny doniczkowe

\section{WSTĘP}

Zabytkowe zespoły zieleni pełnią funkcje historyczne, przyrodnicze, naukowe, artystyczne i użytkowe. Po wieloletnich zaniedbaniach próbuje się odnowić wiele takich obiektów. Prace rewaloryzacyjne powinny być prowadzone wszechstronnymi metodami, należą do nich m.in. kwerenda materiałów archiwalnych. Ważnym jest, aby dobór wyposażenia nawet tak małych elementów, jak pojemniki na rośliny, był wykonany z jak najlepszą wiedzą i najwyższą starannością.

\section{MATERIAŁ I METODYKA}

Podjęcie tematu miało na celu odpowiedź, jak wyglądały pojemniki na rośliny stosowane w dawnych ogrodach. Badania polegały na kwerendzie materiałów archiwalnych tj. ikonografii i map oraz wizji terenowej wybranych dawnych zespołów architektury rezydencjonalnej.

\section{WYNIKI}

Pojemniki są ważnym elementem wyposażenia ogrodu historycznego. Dawniej donice były wykonywane z materiałów, takich jak: ceramika, terakota, kamień, drewno, brąz i ołów. W XIX w. masowo produkowano pojemniki z żelaza, które jednak bardzo łatwo rdzewiały [Harrison 2010]. W ogrodach historycznych pojemniki ustawiano w punktach, które chciano podkreślić, lub formowano z nich rzędy i rytmiczne kompozycje. Donice ustawiano nad brzegami zbiorników wodnych, na balustradach, tarasach i schodach. Głębokie i szerokie donice terakotowe służyły głównie do uprawy drzewek cytrusowych. W płytkich pojemnikach sadzono rośliny z ogródków alpejskich. Niekiedy stosowano skrzynie podobne do sarkofagów, często ozdobione reliefami w kształcie girland. Drewniane, sześcienne skrzynie nazywano pojemnikami wersalskimi. W szklarniach można było spotkać żardiniery z kutego żelaza, na których ustawiano kilka mniejszych doniczek.

Zwyczaj ozdabiania ogrodów pojemnikami sięga antycznego Rzymu, a donice powszechnie stosowano w ogrodach renesansie i baroku. W pojemnikach najczęściej uprawiano egzoty: bugenwillę, daturę, lawendę, pomarańcze, granaty, cytryny, drzewa laurowe, jaśminy, rozmaryny, oleandry i palmy [Siewniak i Mitkowska 1998]. Pojemniki z kamienia i terakoty bywały bogato zdobione właściwymi odpowiedniej epoce stylowej lub malowane we wzory - glazura, majolika. 
Egipcjanie byli pierwszymi, którzy używali pojemników do przenoszenia roślin z jednego miejsca do drugiego. Przenoszenie drzewa w koszu zostało przedstawione m.in. na malowidle $\mathrm{z}$ grobowca w Tebach (ok.1567-1320 p.n.e.). W Atenach, doniczki gliniane wrzucano do morza podczas festiwalu ogrodach Adonis, prawdopodobnie, jako symbol przedwczesnej śmierci Adonisa. $Z$ tej okazji, kobiety również umieszczały kwiaty w donicach na szczytach domów. Teofrast (371-287 p.n.e), wspomina, że roślina zwana południowym drewnem została przywieziona i była uprawiana w doniczkach [Birch 1858].

Wiszące ogrody w Babilonie były w rzeczywistości ogrodem z roślin pojemnikowych. Pojemniki faktycznie nie ,wisiały”, ale były to rośliny posadzone na krawędzi tarasu lub platformy. Niedokładne tłumaczenie słowa „wiszące” pochodzi od greckiego słowa „kremastos” lub łacińskiego „pensilis”, co oznacza „zwisające” [Prior 2012].

W celu dekorowania domów (wnętrz i elewacji) oraz posągów bóstw, Grecy uprawiali ozdobne rośliny w pojemnikach. Naczynia te były zdobione w ten sam sposób, co ściany budynków - ornamentami o tematyce florystycznej. Przedstawiały drzewa, krzewy, kwitnące rośliny oraz warzywa, które w tym czasie uprawiano: lilie (Lilium sp.), kosaćce (Iris sp.), róże (Rosa sp.), granaty (Punica sp.) czy mirty (Myrtus sp.). Palmy daktylowe (Phoenix dactylifera) utrwalone na naczyniach minojskich świadczą przykładowo o intensywnej wymianie handlowej z Egiptem [Majdecki 2010].

W IV w. p.n.e. wykształcił się klasyczny dom grecki - zamknięty od ulicy ścianą z drzwiami wejściowymi, wewnątrz którego znajdował się prostokątny dziedziniec otoczony kolumnadą portyku. Większość dziedzińców wewnętrznych wyłożona była posadzką kamienną i ozdobiona roślinami $w$ donicach oraz rzeźbami.

W budynku mieszkalnym z czasów rzymskich wszystkie elementy założenia znajdowały się na głównej osi kompozycyjnej, jako oddzielne wnętrza następujące kolejno jedno po drugim. Początek stanowił westybul, za nim było atrium - dziedziniec $\mathrm{z}$ basenem do gromadzenia wody opadowej oraz rośliny w donicach.

W Pompejach odkryto całą gamę ceramiki, w której prawdopodobnie uprawiano rośliny. Cesarz Hieron zbudował statek, z siedziskami wysadzany klejnotami, kolorowymi żaglami, dużymi łazienkami, werandami i jadalniami na pokładzie, ozdobiony winoroślą i drzewami owocowymi [Gothein 1914]. Na freskach z Bosco widoczne są trzy proste, podobne w formie do niskiej kolumny pojemniki z roślinami. Donice stoją na bazie, a ich ścianki zdobią żłobienia (tzw. kanelury) [Ryc. 1].

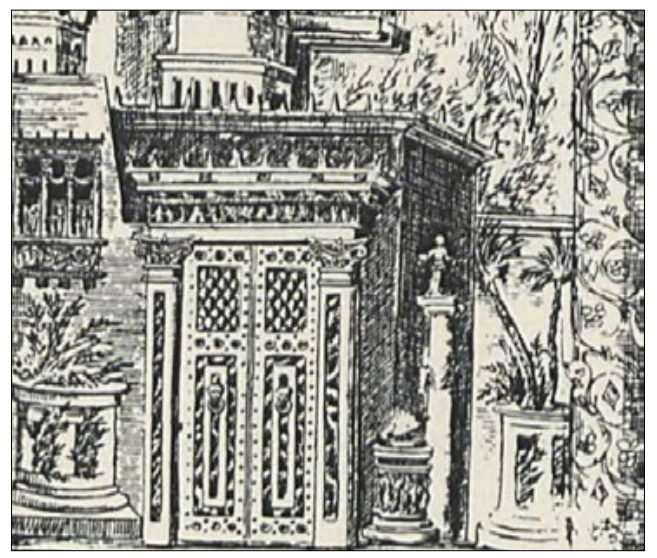

Ryc. 1. Fragment ryciny przedstawiającej freski z Bosco [Gothein 1914]

Fig. 1. Fragment of fresco depicting figures from Bosco [Gothein 1914] 
Mała architektura ogrodowa występująca w ogrodach średniowiecznych miała przede wszystkim znaczenie użytkowe. Jak ukazuje ikonografia donice ceramiczne służyły do uprawy roślin kwiatowych i ziół. N rycinie z XV w. widoczne są; łąka pod murami miasta, przepływający strumyk, żywopłoty pełniące funkcję ogrodzenia, sześciokątny stół oraz roślina w prostej donicy (Ryc. 2). Na jednej z kart z Brewiarza Grimani również znajduje się rysunek dwóch donic, wykonanych prawdopodobnie z gliny, z podstawkami i uszkami do przenoszenia (Ryc. 3). Obraz Wiosna [1607] przedstawia ludzi pracujących w ogrodzie, a na ścieżce pomiędzy kwaterami stoją gliniane donice $\mathrm{z}$ roślinami.
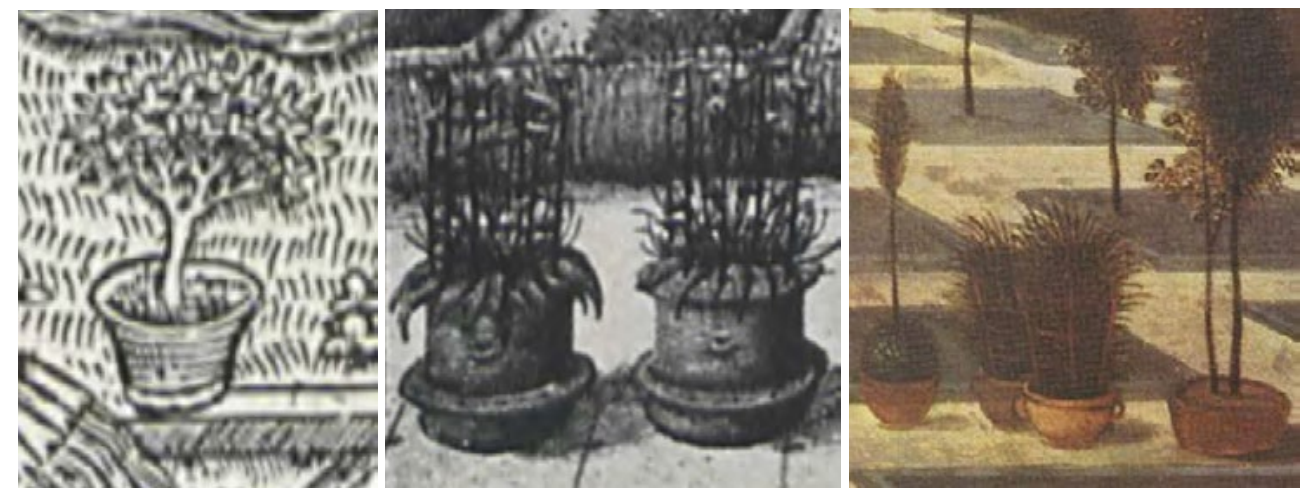

Ryc. 2. Fragment ryciny „Ogród miłości”; ryc. 3. Fragment ryciny z Brewiarza Grimani [Gothein 1914]; ryc. 4. Fragment obrazu „Wiosna” Abel Grimmer 1607 r.

Fig. 2. Fragment of engravings "Garden of Love"; fig. 3. The section drawings of the Breviary Grimani [Gothein 1914]; fig. 4. Image of the "Spring" Abel Grimmer 1607.

Wartościową pozycją w badaniach ikonograficznych była książka z 1914 r. pt. „Gesichte der Gartenskunst" zawierająca przedruki jeszcze dawniejszych rycin. Na ilustracjach przedstawiających wiele europejskich ogrodów widoczne są pojemniki z różnego rodzaju roślinami, np. w Willi D’Este pojemniki z drzewami rozstawione były na parterze wodnym, palmy i rośliny egzotyczne znajdowały się nad wodotryskami, wzdłuż Ulicy Fontann i na balustradach schodów. Inne rysunki przedstawiają: Willę Pamfili (donice ceramiczne ustawione są na balustradach wokół parteru znajdującego się na pierwszym tarasie ogrodu, za pałacem); Willę Borghese w Rzymie (donice ceramiczne ustawione na balustradzie wokół dziedzińca głównego; Willę Aldobrandini (donice zdobią główny podjazd pod pałacem, szczyt teatru ogrodowego i balustrady tarasu widokowego); Willę Matei (większe i mniejsze donice w rytmicznym układzie na balustradach wokół dziedzińca głównego).

Typowy ogród ozdobny z epoki renesansu mieścił się za pałacem, na głównej osi kompozycyjnej. Geometryczne kwatery były przedzielone ścieżkami. Partery miały początkowo proste wzory, z nisko strzyżonego mirtu (Myrtus sp.), rozmarynu (Rosmarinus sp.), lawendy (Lavandula sp.), ligustru (Ligustrum sp.) lub bukszpanu (Buxus sempervirens). Stosowano okalające brzegi kwater topiary - drzewa i krzewy strzyżone w bryły geometryczne i zwierzęta. Rośliny kubłowe sytuowano w pobliżu fontann (Ryc. 5.), na parterach, ustawiano je na murach ogrodowych i balustradach. 


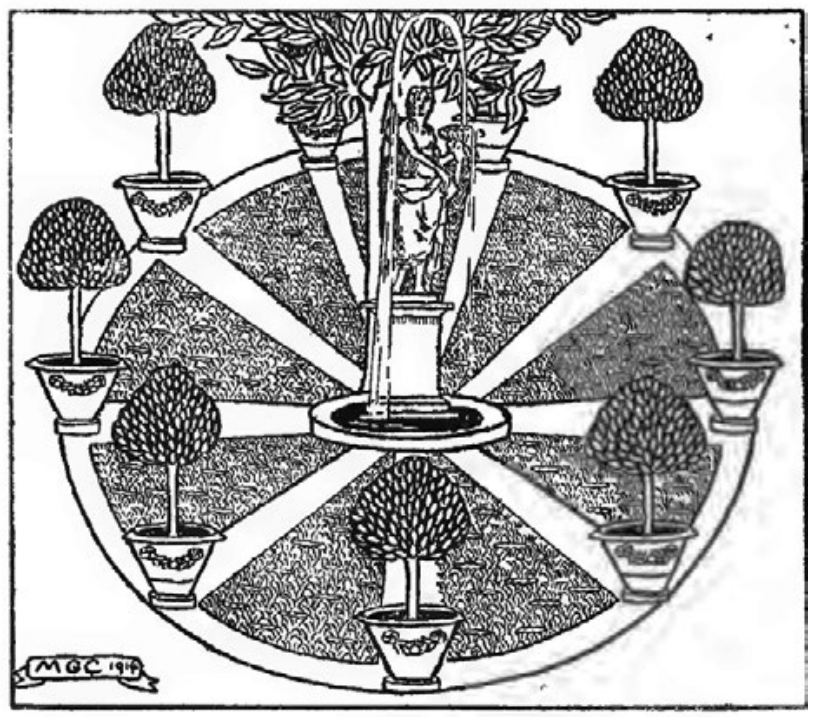

F10. 48 .

Ryc. 5. Rośliny posadzone w donicach na cytrusy, wykonanych z terakoty wokół fontanny [Wolseley 1919]

Fig. 5. Plants in pots made of clay around the fountain [Wolseley 1919]

Barok, jako nowy kierunek w architekturze, podobnie jak renesans wywodzi się z Włoch. Trwał od XVI do połowy XVIII wieku. Lecz to Francja okazała się kolebką w dziedzinie barokowego stylu ogrodowego. Maniera ta charakteryzował się rozmachem, wielkością, a oś kompozycyjna była prowadzona od budynku mieszkalnego ku zanikającemu na horyzoncie punktowi, dzięki któremu przestrzeń ogrodu wydawała się rozciągać w nieskończoność. Bryła pałacu miała swoje odniesienie w poszczególnych wnętrzach ogrodu. Początkiem założenia był dziedziniec $\mathrm{z}$ drogą dojazdową do pałacu w kształcie gęsiej stopki. Budynek wraz z bocznymi skrzydłami okalał dziedziniec honorowy, a za nim znajdował się - otoczony boskietami - salon ogrodowy, najbardziej reprezentacyjna część założenia. Wersal był wzorem dla nowo powstałych, bądź przebudowywanych ogrodów w całej Europie, powielano m.in. zastosowanie drzew pomarańczy w kubłach i ustawianie urn.

André Le Nôtre i jego pomocnicy stworzyli modę na partery ogrodowe. Powierzchnia parteru była płaska, a w jego centrum umieszczano fontannę. W pierwszej połowie XVIII w. chętnie stosowano kwiaty cebulkowe. Uprawiane w doniczkach były w ciągłym pogotowiu tzn. wymieniając doniczki można było z dnia na dzień uzyskać zmianę barwy wybranej części parteru np. z żółtej (żonkile) na niebieską (np. hiacynty). Rośliny kubłowe, spotykane w każdej z wcześniejszych epok, w baroku uprawiane były w oranżeriach. Znajdowały się one na terenie ogrodu, jako wolno stojące lub wbudowane pod tarasem budynki. Pomarańcze (Citrus sp.), granaty (Punica sp.), laury (Laurus sp.) i mirty (Myrtus sp.) wynoszono latem na zewnątrz, ustawiając rośliny w szpalerach pojedynczych lub podwójnych wzdłuż dróg lub rabat, pokrytych piaskiem, tworząc parter oranżeriowy. Bogate i różnorodne formy roślinne stosowano dzięki gatunkom rodzimym, które częściowo były uzupełniane roślinami introdukowanymi.

Ówczesne wnętrza parkowe Wersalu zostały uwiecznione m.in. w pozycji pt. Vues des belles maisons de France [1753]. Pojemniki z terakoty ustawione były m.in. wokół zbiorników wodnych w Sali Festynowej, wokół Fontanny Piramida, w alejach (Ryc. 1,2) i placach. Natomiast palmy, drzewa pomarańczowe i migdałowe oraz granaty w drewnianych skrzyniach, rozstawione były na parterze oranżeryjnym (Ryc. 3). 


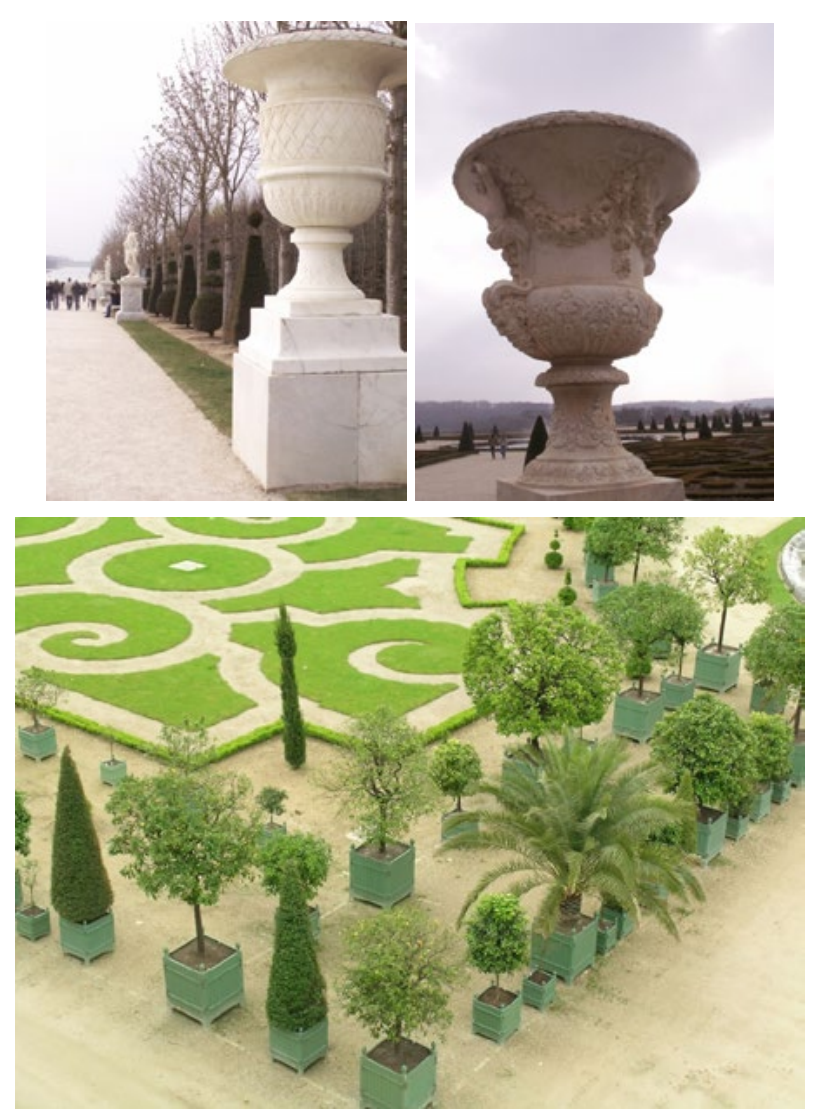

Ryc. 1, 2. Wazy w alejach Wersalu, 2012 r. [fot. E. Pogroszewska]; Ryc. 3. Pojemniki w formie skrzyni na Parterze Oranżeriowym; Wersal (Francja), 2011 r. [fot. M. Dudkiewicz]

Fig. 1, 2. Vases in the alleys of Versailles, 2012 [photo E. Pogroszewska]; Fig. 3. Containers in form of a box on Parterre de l'Orangerie; Versailles (France), 2011 [photo by M. Dudkiewicz]

Na terenie Polski szczególnego znaczenia nabrało dążenie do okazałości i sarmackiego przepychu. Ogrody królewskie i magnackie - zamkowe i pałacowe obejmowały odpowiednio pałac lub zamek, ukształtowany przestrzennie wraz z otaczającym dziedzińcem i ogrodem. Poszczególne elementy połączone osią kompozycyjną to: dojazd i brama wjazdowa, dziedziniec, budynek mieszkalny oraz ogród tarasowy lub płaski. Kwatery były stosunkowo niewielkie, podzielone na regularne kwadraty. W klimacie Polski pojemniki z roślinami były na zimę przenoszone do pomieszczeń, a w lecie wystawiane do parku. Eksponowano je w sąsiedztwie rezydencji lub oranżerii.

Ogród angielski był kształtowany na wzór naturalnego krajobrazu, i traktowany podobnie jak kompozycje malarskie. Kwiaty w pojemnikach ustawiano na gazonie, który znajdował się na wprost wejścia do budynku pałacu, wzdłuż biegu schodów, na parterach przez pałacem, na balustradach schodów terenowych i tarasów widokowych. Przedstawiają to m.in. zachowane materiały ikonograficzne majątków: Wiejkowo (dawna nazwa Gross Wackow) powiat kamieński, Glisno (Gleissen) w powiecie sulęcińskim, Potulice pow. nakielski, Morawa (Muhrau) pow. świdnicki, Kolęda (Collande) pow. milicki, Sambórz (Polnisch-Tschammendorf) pow. średzki, Dziadów Most (Gross Ulbersdorf) pow. oleśnicki, Dalków (Dalkau) pow. polkowicki, Kliszów (Klieschau) pow. lubiński, Sławnikowice (Kieslingswalde) pow. zgorzelecki, Iłowa (Schlesisch-Halbau) pow. żagański, Janiewice (Jannewitz) pow. sławieński i wiele innych. 
Przy czym szczególnie interesującą pozycją w przeprowadzonych badaniach ikonograficznych było 16 tomów z 960 litografiami i tekstami opisów rezydencji w Prusach pochodzących $\mathrm{z}$ lat $1857-1883$.

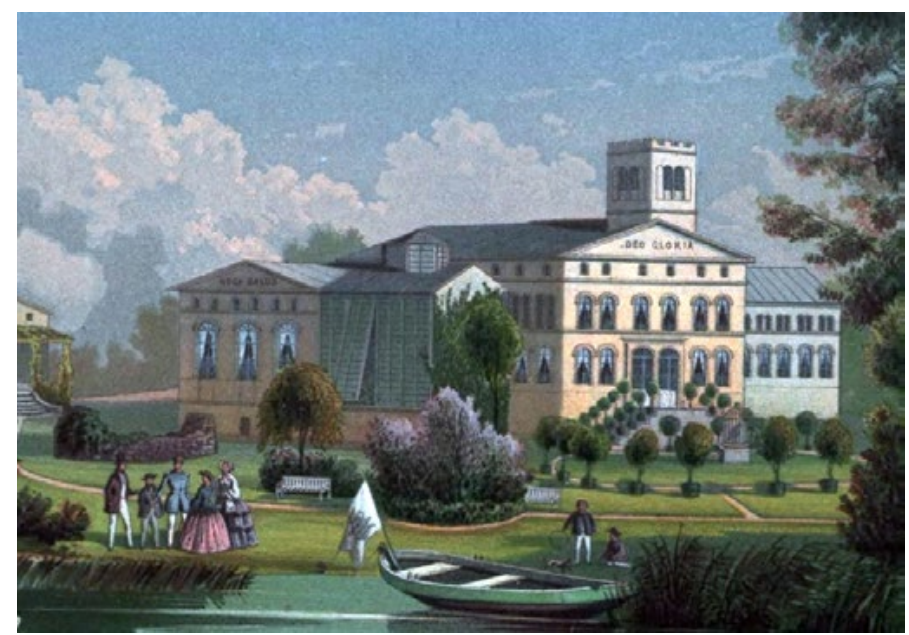

Ryc. 5. Kubły ustawione na podjeździe przed pałacem Wiejkowo powiat kamieński [Anonim, zbiór litografii 1857-1883]

Fig. 5. Containers in the driveway in front of the palace in Wiejkowo commune Kamien [Anonymous, a collection of lithographs 1857-1883]

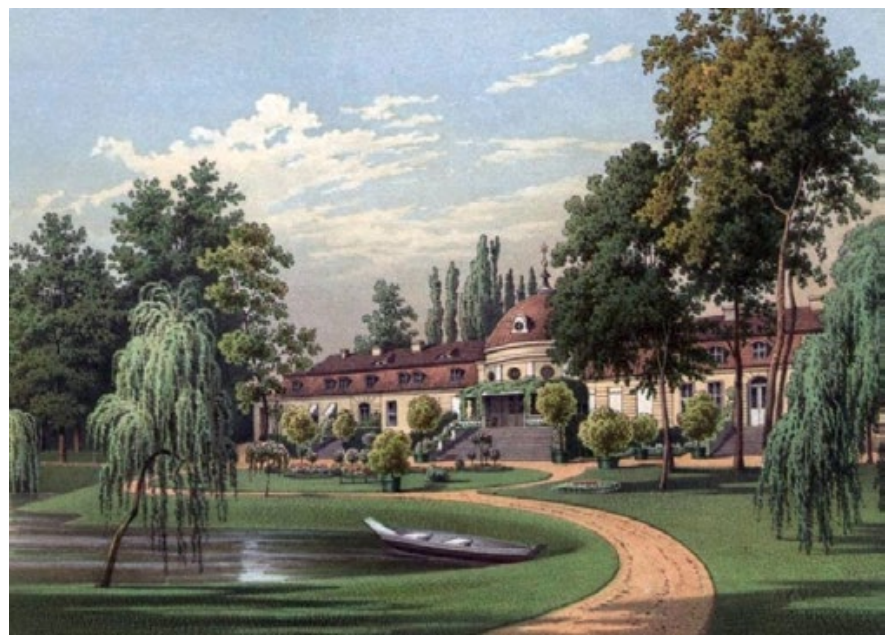

Ryc. 6. Kubły ustawione na podjeździe przed pałacem Glisno powiat sulęciński [Anonim, zbiór litografii 1857-1883]

Fig. 6. Containers in the driveway in front of the palace in Glisno commune Sulęcice [Anonymous, a collection of lithographs 1857-1883] 


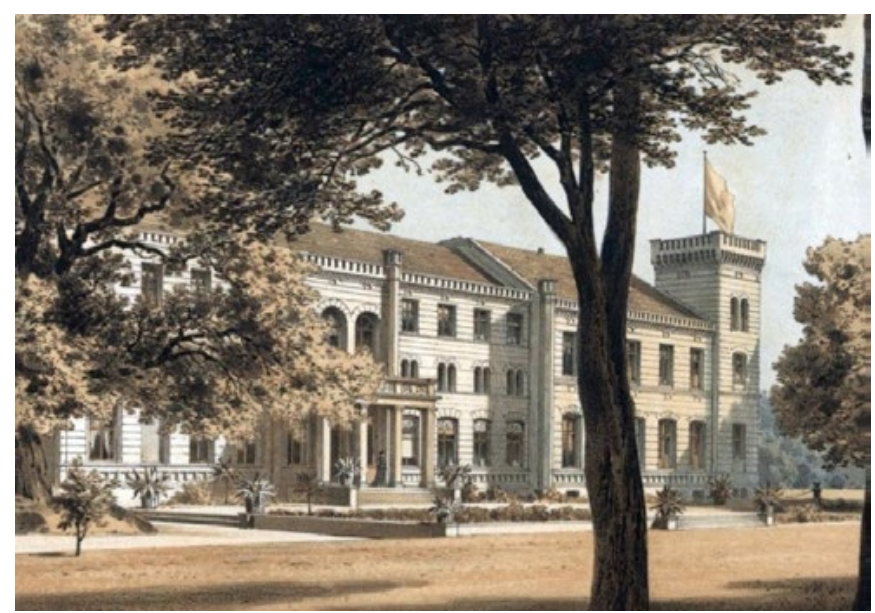

Ryc. 7. Agawy w donicach wokół pałacu w Potulicach powiat nakielski [Anonim, zbiór litografii 1857-1883]

Fig. 7. Agaves in pots around the palace in Potulice commune Nakło [Anonymous, a collection of lithographs 1857-1883]

Sprowadzane krzewy ozdobne (np. azalie), drzewka cytrusowe, palmy, agawy czy jukki, charakteryzowały się dużymi wymaganiami cieplnymi. Uprawiano je w oranżeriach lub wnętrzach pojemnikach, a latem wystawiano na tarasy, partery kwiatowe i gazonowe [Pudelska i Rudnicka 2010]. Do dużych roślin używano kubłów drewnianych - dębowych lub sosnowych [Jankowski 1900]. Kubły wykonywano z klepek, pojemnik był wewnątrz wypalony, a na dnie osmołowany i przedziurawiony, obity żelaznymi obręczami, z dwoma uchwytami do przenoszenia (Ryc. 4) [Jankowski 1880]. Kułby wykonywano w kształcie okrągłym albo „graniaste na nóżkach stojące” czyli sześcienne, tzw. pojemniki wersalskie (Ryc. 5) [Wodzicki 1820].
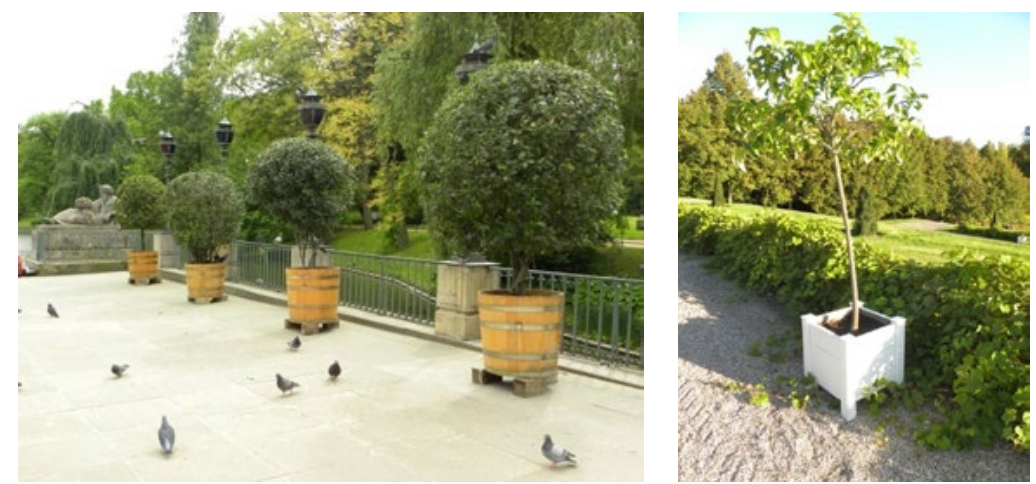

Ryc. 4. Formowane drzewa laurowe w kubłach na tarasie przy Pałacu Łazienkowskim, Warszawa;

Ryc. 5. Drzewko cytryny w pojemniku typu wersalskiego w Sanssouci (Niemcy); 2012 r. [fot. M. Dudkiewicz]

Fig. 4. Molded laurel trees in buckets on the terrace at the Palace Lazienki, Warsaw;

Fig. 5. Lemon tree in a container of Versailles in Sanssouci (Germany), 2012 [photo by M. Dudkiewicz]

Fragmenty kamiennych lub ceramicznych donic należą do interesujących znalezisk archeologicznych podczas prowadzonych prac wykopaliskowych. Pojemniki dekoracyjne są źródłem cennych informacji, przydatnych w ustalaniu rodzaju uprawianych dawniej roślin oraz ułatwiających odtwarzanie układu kompozycyjnego ogrodu. Przeprowadzona analiza fragmentów donic z prac wykopaliskowych w Wilanowie wykazała, w przypadku donic 
o formie zbliżonej do misy sadzono w nich prawdopodobnie drzewka cytrusowe. W ogrodzie wilanowskim natrafiono także na liczne fragmenty donic, które wkopywano w ziemię aż po górną krawędź wylewu, a sadzono w nich rośliny cebulowe, bulwiaste lub o korzeniach palowych. Wkopywanie doniczek w podłoże miało zastosowania praktyczne, do których należały: oszczędność wody do podlewania, zabezpieczenie przed gryzoniami oraz łatwość wyjmowania roślin $\mathrm{z}$ donic na okres zimowania. W trakcie wykopalisk natrafiano również na inne wyroby ceramiczne, takie jak fragmenty ceramicznych kloszy służących do nakrywania na noc szczególnie cennych roślin, co chroniło np. szparagi, seler naciowy czy cykorię przed niskimi temperaturami i zwierzętami [Morysiński 2006]. Ryciny 6 i 7 przedstawiają bogato zdobione pojemniki na rośliny w parku w Wilanowie.
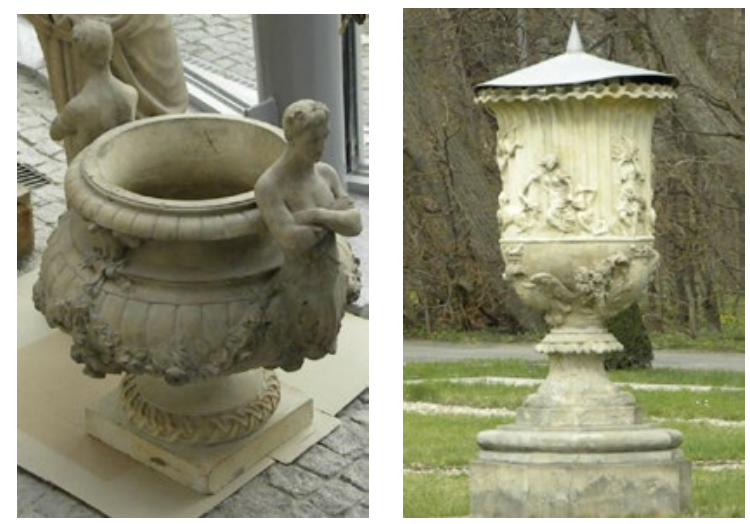

Ryc. 6. Waza (1858) podczas renowacji; Ryc. 7. Waza ogrodowa na parterze Ogrodu Włoskiego; Zespół pałacowy w Wilanowie, 2011 r. [fot. M. Dudkiewicz]

Fig. 6. Vase (1858) during the renovation; Fig 7. Vase garden on the ground floor of the Garden Italian; The palace complex in Wilanów, 2011 [photo by M. Dudkiewicz]

Jak wynika z analizy zebranych materiałów ikonograficznych i przeprowadzonych badań terenowych pojemniki parkowe służące do ekspozycji roślin przyjmowały kształty: donic (szerokość pojemnika zbliżona do jego wysokości; donice ustawiano bezpośrednio na ziemi lub niewielkiej bazie), mis (szerokie naczynia), urn ogrodzeniowych (ustawiane w układzie rytmicznym na szczycie ogrodzenia), amfor (wysokie, smukłe naczynie z dwoma umieszczonymi symetrycznie po bokach uchwytami), waz, kwietników (na kilka okazów roślin), skrzyń (kubłach) o podstawie koła lub kwadratu z opaskami stalowymi oraz pojemników wersalskich. Często dla celów estetycznych misy, wazy, amfory i urny ustawiano na postumentach (Fig. 8, 9).
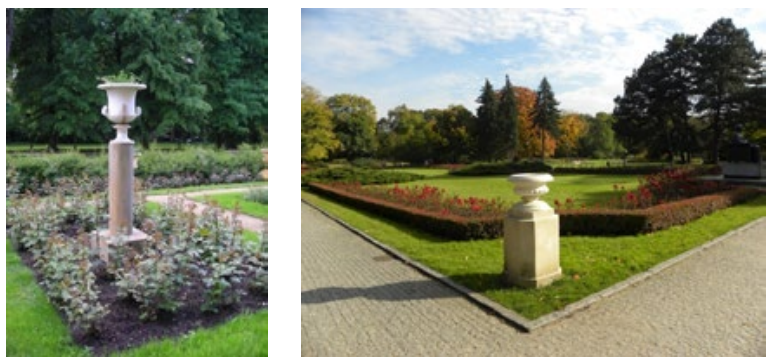

Ryc. 8. Waza na postumencie, na kwietniku z róż, Łańcut, 2011 r. [fot. M. Dudkiewicz] Ryc. 9. Misa na postumencie, Park Ujazdowski, Warszawa 2011 r. [fot. M. Dudkiewicz] Fig. 8. Vase on a pedestal, the flowerbed of roses, Łańcut, 2011 [photo by M. Dudkiewicz] Fig. 9. Bowl on a pedestal, Ujazdowski Park, Warsaw, 2011 [photo by M. Dudkiewicz] 


\section{PODSUMOWANIE}

1. Pojemniki stanowią nieodłączną część wyposażenia reprezentacyjnych części historycznych ogrodów.

2. W kompozycji ogrodu pojemniki pełniły rolę akcentów wnętrz ogrodowych, ozdabiały balustrady, biegi schodów terenowych, tarasy i krawędzie zbiorników wodnych.

3. Ze względu na kształt pojemniki ogrodowe można podzielić na: donice, misy, wazy, amfory, urny, kwietniki, skrzynie (kubły) i pojemniki wersalskie.

4. Oprócz zadań praktycznych np. uprawa ziół, pojemniki spełniały również rolę estetyczną, ozdabiając miejsce, w którym się znajdowały.

\section{PIŚMIENNICTWO}

Birch S., 1858. History of Ancient Pottery. J. Murray, s. 202.

Furmanik B., 2010. Dobory materiałowe w ogrodach zabytkowych, [w:] Kurier Konserwatorski 7: 23-31.

Harrison L., 2010. Jak czytać ogrody, Wyd.Arkady, Waraszawa.

Gothein M. L. 1914. Geschichte der Gartenkunst, Jena.

Jankowski E., 1880. Kwiaty naszych mieszkań, Warszawa.

Jankowski E. 1900. Ogród przy dworze wiejskim. Warszawa.

Morysiński T., 2006. Archeologia procesie rewaloryzacji ogrodów [w:] Wiadomości konserwatorskie nr 19. s. 30-37. Siewniak M., Mitkowska A. 1998. Tezaurus sztuki ogrodowej, Oficyna Wydawnicza Rytm. Warszawa.

Perelle., 1753. Vues des belles maisons de France.

Prior M., 2012. The History of Container Gardening. http://www.ehow.com/about_5459434_history-container-gardening.html stan z dn. 27.12.12 r.

Pudelska K., Rudnicka E. 2010. Ogrody zimowe na przykładzie oranżerii dworskich $w$ Milanowie $w$ Powiecie Parczewskim. [w] Teka Kom. Arch. Urb. Stud. Krajobr. - OL PAN, s. 56-62.

Wodzicki S., 1820. O chodowaniu, użytku, mnożeniu i poznawaniu drzew, krzewów, roślin i ziót. Kraków.

Wolseley V., 1919. Gardens their form and design. London.

Zbiór litografii. 1857-1883. 16 tomów z 960 litografiami i tekstami opisów rezydencji w Prusach. Berlin.

\section{CONTAINERS AND PLANTS IN HISTORIC PARKS AND GARDENS}

Abstract: Containers are an important part of the historic garden equipment. The flowers were planted in pots and bowls in the times of Homer. In the gardens of the historic seventeenth, eighteenth and nineteenth centuries containers erected at points that they wanted to emphasize one formed rows and rhythmic compositions. Pots erected on the banks of reservoirs, the balustrades, terraces and stairs.

Keywords: palace, mansion, containers, potted plants 